\title{
Both/And: The Alternative of Relational Thinking
}

\section{LINDA HUTCHEON}

To call the issues facing departments of English today difficult or sensitive would obviously be understating the case. Chairs would be forgiven if they had nightmares about the incommensurability of the demands made on them and the kind of institutional and collegial support they can count on. Some of the problems they face are internal ones, such as how to deal with the ideological factionsoften generationalwithin departments. Others are more public: how to justify our discipline to a population indoctrinated with the notion that what we do has been irremediably politicized, rendered incapable of disinterested intellectual investigation.

Major changes in the social mission and, indeed, the demographics of institutions of higher learning have raised still other issues with which the profession must deal. The subsequent challenges to the canon have meant altered curriculanot always accepted as valid by everyone, as we know. The same changes have brought about a new sensitivity to the rights of groups the dominant culture has belittledrights as students, but also as colleagues. Minority hiring procedures, pay equity concerns, sexual harassment policiesall have come into existence in recent years. Although they have been welcomed by some as positive signs of adjustment to new gender, class, and multicultural realities, such innovations have not been without their opponents and, some would say, their drawbacks.

One element these changes have foregrounded is the increasing institutional power of what has been called a culture of dissent. After several decades of more or less successful political action, conducted in the larger social arena as well as within our institutions by those marginalized by race, gender, sexual orientation, age, ethnicity, and a host of other variables, many have come to accept as necessary (even inevitable) a kind of oppositional or adversarial stance: a them/us position often translating into a have/ have not binary. It is rare to find someone who does notat least some of the timethink in these oppositional terms. And, indeed, binaries may be unavoidable when issues of inequality and imbalance of power are at stake.

What has helped make these particular oppositions even more potent, though, is that the adversarial thinking has dovetailed (structurally and temporally) with the competition model on which our academic 
world is premised. Institutionally, we compete for students, job candidates, operating funds, international reputation; individually, we vie for jobs, research grants, the opportunity to publish. Furthermore, the consumer capitalist model that is, however implicitly, the basis of our profession has been overlaid with a hangover from the Romantic aesthetic: we assume, for instance (and therefore so do our graduate students), that their (and our) dissertations must constitute original contributions to knowledge and that they should then be able to publishthat is, copyright and sell their productions. In short, we have precious little right to be holier than thou about the culture of late capitalism when the message we give to our students, the model on which we organize our departments and our careers, is one of competition and consumption. Because of such underpinnings, the terms of the dialogue about the state of our professionas they have been set for us by the media in the debates about political correctnessdo not seem very useful or relevant, at least no more so now than they might have been in those legendary good old days. Right or left, neoconservative or Marxist, reactionary or revolutionarythese problematic oppositions radically simplify complex relations among people and ideas, institutions and ideals.

The issue here may well be more structural than specific to the current debates, however. Maybe such either/or thinking has finally run its course; maybe it is time for us to deploy a little postmodern both/and thinking and to find a way out of the constant negativity of dissenta negativity that, after a while, gets to be too easy, especially when it comes from the tenured professoriat. As Barbara Johnson put it a few years ago, Simply saying what's wrong with something is not a vision of a better alternative, and it can be that you take a facile position and sit in the middle of something, receive all the benefits that it confers, and act as if seeing its flaws is a sufficient way of distancing yourself from the bad conscience that goes along with it (qtd. in Salusinsky 172). Stepping out of this opposition frame won't be simple, for the culture of dissent has become a familiar and comfortable one for many of us used to defining ourselves oppositionallyand I include myself here. Whether we earned our stripes (our scars?) trying to enter the academy as women, as blacks, as native North Americans, as members of a generation who graduated to face a decade of only part-time and temporary appointments, some of us have been affectively as well as intellectually formed by adversarial politics. The legacy of the 1960s probably makes us question authority, as a once-omnipresent lapel button asserted, makes us see challenge as a positive value in and of itself, even if positive solutions are not forthcoming. Those of us influenced in our professional training and intellectual development by structuralist, poststructuralist, feminist, or other theory may have acquired a need to question the natural, the universal, the eternal, all the notions that went without saying in our culture. Today, although we may realize that our binary thinking has fed into the business model of competition (or even the military model of supremacy), we may still consider it the only possible model for political agency. And we may be right. Nevertheless, the disadvantages of this fearful symmetry of oppositions are becoming apparent in our institutional structures and perhaps even in our modes of thought. Might there be some model of fearless asymmetry (to use my colleague Len Findlay's term) to combat the debilitating and divisive effects of both the negativity of dissent and the competition that either/or thinking invokes?

The most obvious alternative within our traditional liberal humanist frame of reference lies in that Burkean tradition that Northrop Frye described as the model in which opposition forms a larger synthesis instead of an apocalyptic separation of sheep and goats (Conclusion 330). But for those working within the paradigm of postmodernitywith its suspicion of such totalizing syntheses and its incredulity toward metanarrative (Lyotard)a more acceptable model might be some inclusive both/and thinking based on the plural, the multiple, the different, and, above all, the relational and the cooperative. I do not refer to such a conception in a soft and fuzzy, New Age way, but rather in the critical sense in which it has been articulated by groups as diverse as ecologists and feminists, postmodern sociologists and Native storytellers. This kind of thinking is not radically new, of course: within the institution there has always been both collaborative and interdisciplinary work, though the recent move out of disciplinary enclaves 
into areas of broader cultural study perhaps signals something different. Because no text, no art form, no reader, no student or teacher exists in a cultural vacuum, the mutual illumination of relational studies is being advocated by people working from many different critical perspectives today.

Were we able to think more relationally than confrontationally or competitively, we might also get rid of the idea of some we studying some it or them . In anthropology, of course, the ethics of studying theother has been the topic of major debates lately; in the literary domain, the issue has usually been articulated in terms of the appropriation of voicemost strongly, in Canada recently, by Native writers and storytellers. A more relational model might allow us to study relations among groups, among texts, while carefully positioning ourselves within (not outside) those complex relations and while accepting the resultant partiality and provisionality of perspective as inevitable but not invalidating.

What good would that kind of conceptual change do, however, if it left unaltered the institutional model of systemic and systematic opposition and competition that frames our careers? From the dissertation onward, as I mentioned earlier, the premise is that our scholarship is originalthat is, we seem to have accepted a (now-contested) notion of uniqueness that presupposes an academic ideology analogous to the Romantic one of the poet as original genius. To demonstrate our uniqueness, in our world, we sometimes even have to question the uniqueness of others; we must show how they are wrong and we are right. My argument here is not with any possible truth claim; I merely wonder whether this notion of individuality and competition is an accurate modeling of the reality of the intellectual process. Isn't the way we think and do research based, in fact, more on learning from the work of others, on building on (even if we disagree with) the thinking of others? Just as texts have meaning in relation to other texts, maybe we too should situate ourselves within a relational model. That is the implied message of a whole series of theorists, from the humanist Frye to the structuralists to certain feministsadmittedly in their different ways. Perhaps perversely, I would suggest that something as seemingly bizarre as the digital sampler, used in music production today, is a more accurate and appropriate relational model for what we do than the Romantic idea of individual genius. And, I would quickly add, to make such an assertion is not in the least to down-play the importance of our endeavors.

\section{II}

Permit me to illustrate this point by switching on my personal academic sampler for a moment: we live and teach today in a postmodern space, the spacedescribed in terms of supplementarity (Derrida 243), reduplication (Crimp 44), intertextuality (Kristeva 255)in which it is only as part of prior discourses that any text derives meaning and significance (Hutcheon 126). It is in such relational space that samplingmusical or literary occurs. The digital music computer, potentially the most postmodern musical instrument yet invented, can digitally encode any sounds, store them, and enable the manipulation and reproduction of those sounds, thus eroding the divisions not just between originals and copies but between human- and machine-performed music and putting authenticity and creativity in crisis (Goodwin 261-62).

What advice can we give, then, to a graduate student writing a thesis in what has been called the postmodern appropriation culture (Ross 212), in which the values of property, ownership, and authenticity are replaced with those of appropriation, sampling, and parody? How do we define the goal and function of an original dissertation in an age of electronic reproduction in which reproduction, pastiche and quotation, instead of being forms of textual parasitism, become constitutive of textuality (Wollen, qtd. in Goodwin 258)? What happens to our implied scholarly ideology of singularity, 
originality, and authenticity in a postmodern Age of Plunder (Goodwin 267)? One way to look at the situation is that we always live in a marketand therefore always find it economical to pay others to locate and sample some of the vast array of possible goods available to us in our supermarket of late capitalist culture (Smith 99).

These samplings we call reviews. Sometimes we call them theory, though: Samuel Weber's article Reading and Writingchez Derrida is about Derrida's La carte postale and its motifs of repetition, iteration and reversible circulation (Smith 207n40), but Weber's deconstructive text itself, at many points, both incorporates and paraphrases Derrida's text (Smith 207n40)thus enacting thetransformative disruptive power (Weber, qtd. in Smith 119) of repetition, or sampling, already activated in Derrida's own text. But is this really new? In earlier centuries, too, samplinga.k.a. copyingplayed a key role in academic training and in the work of an artist such as Ingres, where his lifelong repetition and recycling of themes, compositions, and single figures puts into question the very notion of the original (Buskirk 96-97).

One commentator has isolated three strands of digital sampling in pop production, and I suggest that these three have exact analogues in the work of departments of English today. First, hidden samplingsteal [ing] motivated largely by economicsis what we call plagiarism. The more explicit samplings that celebrate playfulness and deconstruct the original text but remain a radicalism [that] takes place in the mainstream is what some would call deconstruction. Then there are those who have made an aesthetic out of sampling a politics out of stealing (Goodwin 270, 271). This group includes the Foucauldians, with their promoting of anonymous discourse (Patterson 143); it also includes conventional scholarsare not scholarly footnotes but the traces of academic sampling? Even the most traditional scholar, I submit, has in fact been a sampling bricoleur (Lévi-Strauss 18) whose creations always really consist of a new arrangement of elements (21), of messages that have been transmitted in advance (20). Intellectual bricolagescholarshiprepresents the contingent result of all the occasions there have been to renew or enrich the heterogeneous repertoire (17) of culture. Scholars have historically engaged in the business of recycling thereby adding to our already unmanageable stock-piles of cultural waste.

\section{III}

My brief excursion into overt and parodic sampling here is meant not simply to offer an ironic, ecologically correct form of relational knowledge for the 1990s, as we confront (and even resist) a world of information overload in dire need of waste management. With tongue no longer in cheek, I would like to advance that image of the samplerwith its (admittedly problematic) threat to everything from originality and authenticity to copyright and ownershipas perhaps a more apt model for the way we actually think and work. To move from the conceptual level of sampling to that of institution and system, or even individual career, is a big leap, I know, for it is in such sites that both the adversarial and the competitive binaries flourish still, despite our postmodern appropriation culture. Would a more relational mode of thought, however, offer a model more generous and less fraught than the competitive one that risks turning our graduate students into professionalized publishing machines rather than caring teachers, dedicated academic citizens, and fine scholars? I ask this question with real concern, as the placement officer and purveyor of professional skills seminars for one of the largest graduate English departments in North America.

Many of us entered this profession because it gave us a rare opportunity to produce and not only to report on knowledge, to create (through research) rather than simply guard cultureculture as a living thing. And we knew that we had the chance to impart to students (among other things) the skills necessary to do 
research on their ownthat is, to challenge received wisdom, to produce knowledge (see Gilman). That is why we have to continue to do research ourselves, why teaching and research are not separate or separable parts of our job descriptions. But we also have other obligations, ones that are just as important if we are to be good citizens within our academic communities. They include duties perhaps less immediately attractive, or perhaps less clearly rewarded or visibly rewarding: administrative work, committee membership, counseling, supervising, participating in peer review (at all levels), even communicating with the general public in order to avoid damaging accusations of academic parochialism and intellectual elitism. In the anxiety to get a job, then secure tenure, and then promotion, we may sometimes experience a temptationa thoroughly understandable oneto postpone or avoid these citizenship tasks, to leave them to others. Although certainly we all live in a highly competitive world, we must be careful to historicize and to contextualize that fact: it has been that kind of world in the academy for many a year now, and it is not likely to change in any major way soon. We should be willing to take that reality into account, both in the demands we make on others and in the level of engagement we choose for ourselves.

With the privilege of self-governing that characterizes our profession come real responsibilities that a more relational mode of thinking might keep more in the fore-ground of our attention. I would hope that we can find some way to teach what none of us will ever forget: that we have each been helped by others, others who, by their exemplary good citizenship, have made it possible for us to get those doctorates, jobs, tenure, promotions, or grants. For this reason, many of us feel a moral imperative to return the favor for other colleagues and to do our part in the governance of the institution and the profession at largewhatever the (very real) pressures to publish and whatever the (very draining) demands teaching makes on our time and energy. Institutions can obviously help by monitoring their attitudes on these community issues, by examining the message they send out to junior colleagues (and senior ones, for that matter) about the importance of such tasks. But, in the end, the willingness to serve the profession is a matter of individual commitment. Perhaps, if we thought more relationally, we might more easily teach (by example) the notion that skilled professionals should engage their energies in making their scholarly communities workin every sense of that increasingly complex word.

My urge to find a more relational modelboth institutionally and intellectuallymay well come from the fact that I live and work in a country whereCanadian nationalism is an oxymoron, a country that has always had to define itself relationally rather than oppositionally: first as a French and then as a British colony, and always as the neighbor of the much more powerful United States. In the last few years, we have been trying to rewrite our national constitution to enshrine the rights of, but also the common relations among, both French-speaking Quebecois and the aboriginal peoples. Something about Canada's large size and sparse population has given us a sense of having constantly to stay together by making tremendous voluntary efforts at intercommunication (Frye, Conclusion 323). If you have been following any of the Canadian constitutional travails, you will know that those voluntary efforts at communication and even compromise may not have been tremendous enough lately. Northrop Frye, perhaps Canada's best-known theorist and a former MLA president, was being very Canadian when he suggested the dead-end fate of argumentative oppositional thinking that did battle with its implied opposite. That approach was no way, he felt, to create avision that becomes a focus for a community (Divisions 24); such a vision would, instead, have to be in some way a relational one.

A direct corollary of this is that the vision would also have to be a situated onein the sense developed by Donna J. Haraway in her book Simians, Cyborgs, and Women . She argues there the need to talk about the politics and epistemologies of location, positioning, and situating, where partiality and not universality is the condition of being heard to make rational knowledge claims (195). To situate ourselves 
would be a crucial act in relational thinking, though a kind of postmodern modesty might have to prevail if relations were really going to be established outside adversarial models: we might have to renounce the grand postures of the totalizing intellectualthe mastermind, the idiotic subject of Blake's General Knowledgesand to speak instead in a smaller voice as a finite, gendered being bounded by particular horizons, perspectives, experiences, knowledge (Hebdige 11).

In contrast to the acrimony generated by the oppositional terms the media have set for us in the debates on political correctness, we might feel a new sense of tolerance as well as liberation that would come from setting our own terms, and a more relational model of thinking and actingprovisionally, adaptivelymight be worth considering. We need an inclusive imagined community that will recognize and respect but not be divisively defined by generational splits and ideological disagreements; we must negotiate a collective institutional culture and climate in which individuals can meet and talk and listen. The exclusionary binaries of business and adversarial politicsthe us/them and either/or have failed to provide that community for most of us. In times of stress and distress, both our junior and our senior colleagues need the support of community. The challenge will be how to move from dissent to creative construction, from the monad to the community.

The author is Professor of English and Comparative Literature at the University of Toronto. This paper was presented at the 1992 ADE Midwestern Summer Seminarat the University of Waterloo.

\section{Works Cited}

Buskirk, Martha. Commodification as Censor: Copyrights and Fair Use. October 60 (Spring 1992): 82109.

Crimp, Douglas. On the Museum's Ruins. The Anti-aesthetic: Essays on Postmodern Culture. Ed. Hal Foster. Washington: Bay, 1983.43-56.

Derrida, Jacques. Of Grammatology. Trans. Gayatri Spivak. Baltimore: Johns Hopkins UP, 1976.

Frye, Northrop. Conclusion. Literary History of Canada: Canadian Literature in English. Vol. 3. Ed. Carl F. Klinck. Toronto: U of Toronto P, 1976. 318-32.

. Divisions on a Ground: Essays on Canadian Culture. Ed. James Polk. Toronto: Anansi, 1982.

Gilman, Sander. Whose Classroom Is It Anyway? Teaching and Researching in the Humanities from a Transdisciplinary Perspective. The Discovery/Invention of Knowledge. Ed. J. E. Chamberlin and Linda Hutcheon. Spec. issue of University of Toronto Quarterly 16.1 (1992). 
Goodwin, Andrew. Sample and Hold: Pop Music in the Digital Age of Reproduction. On Record: Rock, Pop, and the Written Word . Ed. Simon Frith and Andrew Goodwin. London: Routledge, 1990. 257-71.

Haraway, Donna J. Simians, Cyborgs, and Women: The Reinvention of Nature . New York: Routledge, 1991.

Hebdige, Dick. Hiding in the Light: Of Images and Things . New York: Routledge, 1991.

Hutcheon, Linda. A Poetics of Postmodernism: History, Theory, Fiction . New York: Routledge, 1988.

Kristeva, Julia. Séméotikè: Recherches pour une sémanalyse. Paris: Seuil, 1969.

Lévi-Strauss, Claude. The Savage Mind . Chicago: U of Chicago P, 1966.

Lyotard, Jean-François. The Postmodern Condition: A Report on Knowledge . Trans. Geoff Bennington and Brian Massumi. Minneapolis: U of Minnesota P, 1984.

Patterson, Annabel. Intention. Critical Terms for Literary Study. Ed. Frank Lentricchia and Thomas McLaughlin. Chicago: U of Chicago P, 1990. 135-46.

Ross, Andrew. No Respect: Intellectuals and Popular Culture . New York: Routledge, 1989.

Salusinsky, Imre. Criticism in Society. New York Methuen, 1987.

Smith, Barbara Herrnstein. Contingencies of Value: Alternative Perspectives for Critical Theory . Cambridge: Harvard UP, 1988.

Weber, Samuel. Reading and Writingchez Derrida. Tildschrift voor Filosofie 45.2 (1983): 41-62.

(C) 1992 by the Association of Departments of English. All Rights Reserved.

\section{ADE Bulletin 103 (Winter 1992): 21-25}

